\title{
Applicable Law to Insurance Contracts in the light of Rome I Regulation - Challenges to Cross- Border Insurance Contracts in the EU
}

Pedro Monteiro de Meireles

\section{The Rome I Regulation choice-of-law rules for insurance contracts - a concise analysis of article 7}

The Rome I Regulation establishes European-wide solutions to determine which national law applies to contractual obligations in civil and commercial matters involving more than one MS. The regulation sets different rules depending on the type of contract in question to better suit the specifics of those contracts, for instance, depending on the contract, whether it is a freight transport, a consumer or even an insurance one, the solutions will likely be different.

What it comes to insurance contracts that involve a conflict of laws, the question of defining the applicable law arises', since these contracts are related with at least one legal order or more, therefore the uncertainty on which legislation will regulate the contract and what criteria will dictate its ending. Unlike a unique internal contract, here it will reveal several points of view regarding other legal orders, either because of the policyholder's usual

\footnotetext{
' The regulation defines which law applies to several aspects of the contract: how to interpret the contract and what to do to comply with its clauses; the consequences of non-compliance with the origins resulting from an agreement, including assessing the damage; the various causes for the termination of contractual obligations (for example, payment, compensation, cancellation of the contract), the statute of limitations and time limits for bringing legal action; and the consequences of the invalidity of the contract.
} 
ULP Law Review | Revista de Direito da ULP

Vol. 13, n. .9

doi: 10.46294/ulplr13n1d5

residence, the insurer's headquarters, or even because of the risk is separately or jointly in distinct legal rules.

One way to address this intricate issue is article 7 of Rome I Regulation, where it was enshrined a special conflict rule, to introduce legal solutions for the correct determination of the applicable law to the cross-border insurance contracts in a European context ${ }^{2}$. Even though the regulation enshrines this norm that focuses clearly on insurance contracts, we already have some hesitations on the efficiency of its legal construction ${ }^{3}$, in particular, about the alleged uniformity that was intended to be established on ${ }^{4}$.

Given the option of dividing contracts into two broad groups, it may raise questions due to contracts that cover large risks and those that include mass risks. Furthermore, there may be an issue of which law will be applicable in cases where the contract consists of both significant risks and mass risks located within the $\mathrm{EU}$, or even knowing the regulation for risks found in the internal market, but which are not located in an EU MS. Such are the cases of the European Economic Area states, such as Iceland, Liechtenstein, and Norway ${ }^{5}$.

\subsection{Insurance contracts covering large risks}

First of all, it is necessary to care about the gap in the Regulation in pointing out the definition of significant risks ${ }^{6}$; instead, it refers us to the explanation contained in Directive

\footnotetext{
${ }^{2}$ Based on this article, we can distinguish the following categories of contracts: i) insurance contracts that cover significant risks (despite whether the risk's location in an MS or a non-EU state); ii) insurance contracts covering mass risks located in an MS; iii) insurance contracts covering mass risks situated in an extra-Community State; iv) reinsurance contracts.

${ }^{3}$ The Regulation covers several contracts that previously did not deserve regulation, «This concerns insurance contracts which are concluded - first - by insurers without domicile or branch in a Member State and - second - for risks situated in a Member States,y Helmut HEISS, Insurance Contracts in Rome I: Another Recent Failure of the European Legislature, (Yearbook of Private International Law 10, 2008), 263.

${ }^{4}$ Which goes against one of the great objectives of the Rome I Regulation, «As such, Rome I being the sucessor of the Convention, will be a connerstone in European Civil law cooperation; its principal purpose is to eliminate forum shopping by harmonizing the choice of law rules for contracts»), 0. LANDO and P. NIELSEN, The Rome I Regulation, (Common Market Law Review 45, 2008), 1688.

${ }^{5}$ HEISS, 266, points out to a plausible solution on this matter, «...... risks, which are located within the internal market yet outside of the Member States of Rome I......are excluded from the scope of article 7 of Rome I and will, therefore in future, be dealt with by Member State courts according to the rules on applicable law in article 3,4, and 6 of Rome I, which were not intended for the internal insurance markets.

${ }^{6} \mathrm{Alarge}$ part of the doctrine argued that article 7 should determine the understanding of significant risks, "This option could be attended by adjustments that may be claimed for the purposes pursued by the Law of Conflicts
} 
ULP Law Review | Revista de Direito da ULP

Vol. 13, n. .1

doi: 10.46294/ulplr13n1d5

2009/138 / EC, which, in its article 13 (27) and subsequent Annex I, points to the concept of high risks.

In this type of contract, the parties can freely settle, by agreement, the law of any State relevant to the contract, following the principle of autonomy of will (art. 7 (2), 1st paragraph, and art. 3).

What it comes to freedom of self-determination of those parties could be limited at first, according to the understanding of the majority doctrine ${ }^{7}$, as in "law chosen by the parties" as being able to relate to any law rules, belonging to a state legal order.

From our point of view ${ }^{8}$, this understanding makes no sense. The expression contained in the law gives rise to the possibility that the parties will be able to choose contract law principles and rules that are correctly recognized by the international community. Such as the European Insurance Contract Principles, for instance, since it is not specific about the nature of the law that the parties can take, whether that law comes from a state legal order or not. In addition to the support of the letter of the law, we have in favor of our position the legislative ratio inherent to the legal text; the previous versions of the Rome I Regulation go precisely in the direction of allowing the choice of these legally relevant private codifications $^{910}$. Whereas the Regulation recitals, specifically recital 13 , admit the inclusion of rules of non-state law in the contract by the parties, even if it allows it in a limited way, by reference. We consider this point to be a little unclear, and a mid-term solution to the one advocated by us, since at the start it will only be allowed, for instance, to introduce contractual clauses from non-state legislative bodies.

and be aligned with the provisions, in matters of international jurisdiction, in art 14. of the Brussels I Regulation ", Luís PINHEIRO, Sobre a Lei Aplicável Ao Contrato de Seguro Perante o Regulamento Roma I, (Cuadernos de Derecho Transnacional 4, no. 2, 2012), 207.

${ }^{7}$ See Luís PINHEIRO, Direito Internacional Privado, Volume II - Direito de Conflitos - Parte Especial, 4a ed., (Almedina, 2015), 330 and Nuno PISSARRA, Breves Considerações Sobre a Lei Aplicável Ao Contrato de Seguro, (Cuadernos de Derecho Transnacional 3, no. 2, 2011), 46.

${ }^{8}$ Following PINHEIRO, Direito Internacional Privado, 331.

${ }^{9}$ See article 3 (2) of the Rome I Regulation Proposal.

${ }^{10}$ This solution rises in the wake of other international instruments, such as the Inter-American Convention on the law relevant to international contracts and the Hague Principles on the choice of law applicable to international commercial contracts, which already allow the determination of non-state rules as applicable law. 
ULP Law Review | Revista de Direito da ULP

Vol. 13, n. .9

doi: 10.46294/ulplr13n1d5

On the other hand, the guarantee of the principle of autonomy of the parties, and its amplitude is maximized by not asking that the chosen law must undoubtedly have a real connection with the contract. Hence there is no room for any control of the interest underlying the choice of the law; for instance, it is allowed to choose Germany's legislation to regulate an insurance contract, even if the risk settled in Portugal, between a policyholder and a Portuguese insurer, both with habitual residence in the same MS.

In the absence of agreement by the parties, or if the choice of law is not valid, subsidiary criteria will be taken into account, which will be that of the insurer's habitual residence (art. 7 (2), 2nd paragraph, 1st part), that is, the place where the central administration is (art. $19(1))^{11}$. If the contract is listed within the scope of a working branch or other establishment located in another State, depending on the terms, this compliance with the obligations arising from there is the responsibility of the office or the other establishment, in these cases, the place the habitual residence will be the location of that branch or other establishment (art. 19 (2)). Such resolution proves to be quite interesting for the Insurers, specifically for the development of their cross-border activity since all insurance contracts that may be listed will be regulated by the same law, unless otherwise agreed upon ${ }^{12}$. This enormous advantage of preventing the insurer every single time from having to negotiate with the policyholders individually, the law that most interests them. Therefore, in the face of uninformed policyholders, it is an even more significant advantage since they will not try to negotiate an applicable law clause, becoming defenseless ${ }^{13}$.

\footnotetext{
"This explication has advantages for Insurers, according to Lovise MERRETT, Choice of Law in Insurance Contracts under the Rome I Regulation, (Journal of Private International Law, 2009), 58, «Even if the insurer does not insert a choice-of-law clause, the policies will all be governed by the law of the state of the insurer This is crucial for insurers wishing to offer cross-border policies because it ensures that all contracts issued by one insurer are governed by the same law».

${ }^{12}$ Celia CAamINIA, Los Contratos de Seguro Del Art.7 Del Reglamento Roma I, (Cuadernos de Derecho Transnacional 1, no. 2, 2009), 35.

${ }^{13}$ FRIAS Hélder, A Escolha Da Lei Aplicável Ao Contrato de Seguro No Regulamento Roma I, (Revista Actualidad Jurídica 27, 2010), 36 «Another value of this legislative option is that the result of applying the legal precept under examination does not depend on the location of the risk, thus avoiding the difficulties associated with its solution.»
} 
ULP Law Review | Revista de Direito da ULP

Vol. 13, n. .9

doi: 10.46294/ulplr13n1d5

This rule is a mere rebuttable presumption, as it runs along, an exception clause is enshrined ${ }^{14} 15$, when it results from a set of circumstances in which the contract presents an intricate connection with a state other than that where the habitual residence of the insurer location, the law of that other State shall apply. This will happen when the risk or the usual residence of the insured is located in a State other than the State of the insurer's habitual residence.

Given this scenario, we can conclude that the solutions stipulated for insurance contracts that cover large risks are not intended to protect policyholders, since, in the absence of a choice of law, the applicable law will be the law of the country the insurer has his residence. Then, policyholders should, beforehand, during the contract negotiation, safeguard their interests when negotiating the law applicable to the insurance contract they intend, since, from the outset, the supplementary legal solution does not grant protection to their interests $^{16}$

One may question the range and value of paragraph number 2 , since its solutions are substantially identical to those of articles 3 and 4 , which means it is applicable to these contracts the same solutions that got excluded from the scope of section 7, and to which the solutions of articles 3 and 4, respectively, which as we can see are contracts that contain

\footnotetext{
${ }^{14}$ Peter GRUBER, 'Insurance Contracts' in Rome I Regulation - The Law Applicable to Contractual Obligations in Europe, Franco Ferrari e Stefan Leible (Coord.), (Sellier European Law Publishers Munich, 2009), 113 «lt has been argued that a rigid connecting factor might have offered more legal certainty than the rebuttable presumption contained in Article 7 (2) sub-par.2».

${ }^{15} \mathrm{Ibid}, 113$ «lf the European lawgiver introduced a rigid connecting factor, judges would probably be tempted to reach similar results by taking recourse to an implied choice of law "demonstrated by the circumstances of the case" (Article 3 par. 1 s.2) As the ascertainment of such an implied choice of law also leaves some leeway to the judge, a rigid connecting factor would probably not have brought about a significantly higher degree of legal certainty».

${ }^{16}$ This lack of protection of the policyholder goes through its unnecessary protection, Rosa Miquel Sala, El 'Nuevo' Derecho Internacional Privado de Los Seguros En El Reglamento Roma I (Anuario Español de Derecho Internacional Privado, 2008), 442 «The policyholder must be protected only if he cannot negotiate on an equal footing with the insurer. contracts on major risks, in which the policyholder personally negotiates the conditions of the coverage received, but without the embargo on insurance on risks, authentic adhesion contracts».
} 
ULP Law Review | Revista de Direito da ULP

Vol. 13, n. .9

doi: 10.46294/ulplr13n1d5

contractual obligations ${ }^{17}{ }^{18}$. Therefore, we do not see any other reason for this autonomization of solutions, but perhaps the reason for ruling insurance contracts that cover higher risks related to the provisions of mandatory insurance (art. 7 (4)) ${ }^{19}$.

\subsection{Insurance contracts covering mass risks}

Concerning insurance contracts covering mass risks (art. 7 (3)) ${ }^{20}$, the freedom of designation by the parties of the applicable law does not apply; there is instead an exhaustive list of criteria for deciding the law applicable to the length of the various subparagraphs. In general, the solutions in paragraph 3 end up returning this type of contract to the law of the policyholder's regular residency ${ }^{21}$.

\footnotetext{
${ }^{17}$ Following Peter GRUBER, "Insurance Contracts", 112 «So as to the choice of law, insurance contracts on large risks are subjected to the exact same rules as all the other contracts directly governed by article $3[\ldots \ldots$.$] The$ text used in Article 7 (2) subpar.2 s.2 is identical with text used in Article 4 (3).The provision leads to a result which would have been achieved by a direct application of Article 4 (2) and (3) provided that - which seems fairly reasonable - the characteristic performance of the contract is effected by the insurer ».

${ }^{18}$ We don't apply the same resolutions as those seen in wide contractual obligations, Lovise MERREET, "Choice of Law", 58 «... . contracts for large risks are governed by the same choice-of-law rules as apply to contracts generally, but without Article $6 \ldots$. This means that even if a contract for a large risk might otherwise be a consumer contract (eg an individual taking out a policy on a yacht) the special rules for consumer contracts do not applys.

${ }^{19}$ Following Nuno PISSARRA, "Breves Considerações", 40; F. ALfÉREZ and G., "The Rome I Regulation: Much Ado about Nothing?," The European Legal Form, 2008, 75, Helmut HEISS, "Insurance Contracts", 268 e Celia CAAMIÑA, "Los Contratos de Seguro", 37.

${ }^{20}$ As a far side note, the definition of mass risks is not present in any European secondary law instrument, in contrast to significant risks. These will be defined by the negative by referencing the definition of significant risks, so mass risks do not fit the concept of substantial risks, such as private car insurance or a work accident insurance for an SME.

${ }^{21}$ As a common rule, the risk is found in the Member State where the policyholder usually resides, in case it is only the policyholder, or where his enterprise is established if he is a legal person. Nonetheless, there are three exceptions to this rule: insurance contracts relating to real estate, where the risk lies in the MS of the property's location; vehicle contracts, where the risk is considered to be in the MS of the registration; and short-term or risk-related insurance contracts that happen during a trip or vacation, in which the risk is examined to be in the MS in which the policyholder has the contract (FRIAS Hélder, "A Escolha Da Lei Aplicável", 36).
} 
ULP Law Review | Revista de Direito da ULP

Vol. 13, n. .1

doi: 10.46294/ulplr13n1d5

What is not perceived here given the variations of existing subparagraphs, but in fact, some of them prove to be of little practical use, such as line b) ${ }^{2223}$, or they may even be counterproductive for the policyholder itself as line c) ${ }^{2425}$.

The location of the risk assumes real importance, according to its location ${ }^{26}$, if it is within the EU, it will befall or not within the scope of article $7^{27}$. When you can track the same risk in different situations, when the risk is in more than one MS, the parties may choose the law of one of those MS, which they deem most convenient, to govern the contract (art.7 (5)). Indeed, the critical moment for the investigation of the location of the risk is the moment of the contract closure. Once the law is settled, not even a change of the risk can lead to a shift in the applicable law.

Moreover, in the cases of subparagraphs a), b) and e), the MS may grant more extensive freedom of choice of the applicable law, a freedom that makes it possible for parties to invoke when one of these cases is at stake. In these situations, the MS will have to apply this more extensive freedom of choice of law, for instance, in cases where the risk is located in Portugal while the policyholder's regular residence is in Spain, both Portuguese laws may apply to the contract as Spanish law, respectively as paragraphs a) and b) of art. 3. Nevertheless, opposed

${ }^{22}$ «lt seems that the best justification for the point (b) could be such cases where the policyholder changes his place of habitual residence after the contract was concluded. . . Such a change, while irrelevant from the point of view of the application of the point (a), could nevertheless play some role under the point (b) and then this it extends the scope of the parties freedom of choice because it makes an ex post choice of the law of the new country of habitual residence available» - Mateusz PILICH, Law Applicable to Insurance Contracts in the Light of the Rome I Regulation, (Studia luridica, 2012, 197-220), 211.

${ }^{23}$ It can be said that the statement only gains true meaning when it possible to locate the risk in a country other than the place of the policyholder's regular residence, for instance, in the case of travel insurance.

${ }^{24}$ In some situations, this rule can harm the policyholder itself, Xandra KRAMER, The New European Conflict of Law Rules on Insurance Contracts in Rome I: A Complex Compromise, (Iffai University Journal of Insurance Law 4, 2008), 14 «The other side of the coin, however, is that a choice of law included by the insurance company, in a situation where the policyholder is a natural person and does not have bargaining power, a choice of law for the lex nationalitatis is valid, even if the policyholder does not have a genuine link with that law».

${ }^{25}$ This section was created for cases where the policyholder, one person only, has a nationality of an MS other than the one he or she habitually resides on the date of the contract's conclusion. If the policyholder is not a national of an MS, the paragraph will not apply.

${ }^{26}$ Opposed to what happens with significant risks, Lovise MERRETT, "Choice of Law", 54 «The result of these rules is that in most commercial cases, which will usually concern large risks, it will no longer be necessary to consider where the risk is situated. Particulary in cases where the risk is partly inside and partly outside the EU this will make the court's job significantly easier».

${ }^{27}$ With an opposing position, comes Peter GRUBER, "Insurance Contracts", 124 «Therefore the rules applicable to mass risks situated in the EU should equally apply to contracts on mass risks situated outside the EU». 
ULP Law Review | Revista de Direito da ULP

Vol. 13, n. .9

doi: 10.46294/ulplr13n1d5

to Spanish law, which is more restrictive, Portuguese law in art. 6 of the Insurance Contract Law guarantees greater freedom of choice for the applicable law by enabling complete freedom of choice by the parties. Consequently, the Spanish courts would have to apply this Portuguese rule, which guarantees greater freedom of choice.

Such solution could point to a particular situation: that each MS courts apply the criteria of foreign national laws instead of applying the very rules of art. 7 (3) 1st paragraph. In other words, a great deal of relevance goes to the national legal systems. The solution given in the Regulation leads us back to the rules of internal orders. This reference to domestic law causes a nuisance to courts, for having to investigate whether national rules grant greater freedom to take an applicable law, which can be extremely complicated and time-consuming given, as a general rule, the complexities in understanding national rules, in terms of applicable law, to the insurance contract.

From where we stand, it may not be the best resolution, because national law is used to solve an issue that should be resolved strictly by the Regulation. Less is noticeable because the European legislator restricted this solution to points a), b) and e) and did not extend it to all points of paragraph 3, as expected. This solution presented by the European legislator makes this diploma an unclear one and, in some instances, without a discernible structure ${ }^{28}$.

In the absence of choice by the parties of the applicable law, the law of the Member State where the location of the risk will apply ${ }^{29}$ (art. 7 (3), 3rd paragraph). On this account, the risk location, as a rule, is in the policyholder's regular residence country, and therefore, the law which the policyholder has a closer connection ${ }^{30}$.

\footnotetext{
${ }^{28}$ In the same strict way, Miquel Sala, "El 'Nuevo' Derecho", 438 «Esta norma, que se podía tolerar en su contexto originário, resulta totalmente inadecuada en el marco de un Reglamento cuya finalidade última es la creación de un DIPr de los contratos de carácter uniforme para todos los Estados miembros. Con ello se quiere conseguir un trato igualitario de los intervinientes en el tráitico económico, y seguridad jurídica, lo que se malogra al transcribi irreflexivamente un precepto originario de una Directiva».

${ }^{29}$ Some doctrine points out some problems around the concept of risk location, Peter GRUBER, "Insurance Contracts", 118 «The Max Planck Institute and Heiss do not argue that the location of risk leads to unfair results. They hold that the definition is overly complex. They do not question the underlying concept, but rather propose a pragmatic simplification».

${ }^{30}$ Ibid, 117 «The Max Planck Institute and Heiss have held the opinion that the location of the risk as an objective criterion should be replaced by a simple reference to the policy-holder's habitual residence».
} 
ULP Law Review | Revista de Direito da ULP

Vol. 13, n. .1

doi: 10.46294/ulplr13n1d5

\section{The dissuasion to cross-border insurance contracts - especially in cases of active demand for insurance}

As we saw in article 7 (3) it does not apply the freedom of designation by the parties of the law applicable to the insurance contract; this type of contracts are subject to the law of the policyholder's habitual residence. This gives room to interpretation if we take into account the distinction between the active and passive insured, neglected in the current wording of article 7, but not in article 6. This happens, respectively, with consumer contracts, where solutions are duly adapted depending on whether the consumer is active or not ${ }^{31}$.

At its edge, the solutions of paragraph 3 of article 7 can only make some sense in a way to protect the passive insured. When we have an insurer exercising or directing its commercial activity, inside or toward the insured country, it can be said that there is a strong link to rule the contract(s) signed by him to the law of that specific country. Whenever this bond is verified, the use of the law from the policyholder's country cannot be a surprise to the insurer at all; he will know in advance when exercising or directing activities in one or specific MS, the law applicable to insurance contracts that it will carry out there will necessarily be the law of that MS. Otherwise, it could be an unreasonable burden to impose on the insured another law than that of his country, on contracts signed by him in his own country with an insurer operating in that market ${ }^{32}$. Hereabouts, the demand of the law of the policyholder's

\footnotetext{
${ }^{31} \mathrm{~A}$ good definition proposal is given by T. THIEDE and J. SCHACHERREITER, The Recent Shiff from the Passive to the Active Consumer, (Austrian Law Journal, vol. 1, 2015), 28: «Passive in this context means that the consumer is not the initiator of the international contract. The passive consumer principally limits his or her demand for goods to his or her home country, and is one who has no intention to enter the international market. A foreign trader, however, pursues the consumer in his or her home country with advertising activities and induces him or her to condude a contract. The consumer thus becomes a party to an international contract because he or she is the target of the commercial activities of a foreign trader, and not because of his or her own desire to trade internationally. The counterpart to the passive consumer is the active consumer, who takes the initiative to enter the international market, for example by traveling to a foreign country in order to condude a contract with a foreign trader».

${ }^{32}$ The insurer may be a national insurer, operating only in that market or not, or a foreign insurer, which also operates in other markets.
} 
ULP Law Review | Revista de Direito da ULP

Vol. 13, n. .1

doi: 10.46294/ulplr13n1d5

residence on the Insurer will eventually make sense in the way of protecting the theoretically weaker party, the interests of policyholders ${ }^{33}$.

This happens because mass insurance contracts are, as a rule, mandatory adhesion contracts in which there is no mediation by the parts of their content; therefore, a solution of these aims to safeguard policyholders by restricting Insurers to act on inappropriate or disproportionate terms on them. Contrarily, high-risk contracts are generally optional and, consequently, there will be a negotiation by the parties of their terms, which implies that there is a tendency for the greater similarity between the parties, and hence there is a total freedom of choice of applicable law (art. 7 (2)).

However, it might be more convenient for the policyholder to apply a foreign law that is more pleasing to his interests; for instance, in the case of taking out insurance provided by a foreign insurer, you may prefer to apply another law, the law of that insurer's residence. In these cases, under paragraph 3 , such a possibility is not conceded and, therefore, the policyholder will not be able to see his interests satisfied. In the absence of a provision that allows him to choose the law he wishes to apply, he will have to be appeased with the law of his country of residence ${ }^{34}$, which is a contradiction due to the alleged protectionist nature of his interests as far as this legal rule should go.

As for active insureds, the legal solutions of paragraph 3 may harm them even more. We are thinking of situations in which the insured, for some reason, for example, lack of supply of the desired insurance product in the country of residence, decides to contract an insurance product in a foreign insurance market. It will be expected that the law of that country will govern the contracts he concludes in that country, and as such, unlike passive insureds, it will not make sense at any time to subject these contracts to the law of the policyholder's EM

\footnotetext{
${ }^{33}$ The same idea as in consumer contracts, in the same way, as in C. BISPING, Mandatorily Protected: The Consumer in the European Conflict of Laws, (European Review of Private Law, vol. 4, 2014), 514: «Consumer protection via conflicts rules means predominantly granting jurisdiction to the courts at the domicile of the consumer and subjecting the legal relationship between a consumer and a business to the consumer 's home law.....the consumer benefits from the applicability of a system of law with which he is familiar and he does not fall foul of the vagaries of foreign systems that might come as a surprise to him».

${ }^{34}$ We believe that the risk location is as well in the insured's country of residence; otherwise, the possibility of applying a foreign law would be possible through line a) of paragraph 3 of article 7.
} 
ULP Law Review | Revista de Direito da ULP

Vol. 13, n. .1

doi: 10.46294/ulplr13n1d5

of residence, but that is what happens through the imposition of the currently restricted solutions of paragraph $3^{35}$.

Thus, with very few exceptions, the insurer will not recognize to be restrained by a law that he does not know; hence he will only accept the contracting of insurance if the law chosen by him is the law of his domicile or some other that he believes best serves his interests. Consequently, it will be an unreasonable burden to impose the obligation to accept the legal regime of the policyholder's residence to insurances bartered by him on the market in his country of domicile ${ }^{36}$.

Given these considerations, it seems to us that the solutions of paragraph 3 of article 7 are not genuinely protective of policyholders, as they are only to a certain extent for passive insureds ${ }^{37}$. They end up proving to be counterproductive in both circumstances, but more clearly in cases of current demand for insurance contracts, by practically eliminating their possibility of success in engaging insurance across borders.

This structure is not helpful to both parties. For the insurer, who agrees to negotiate with one side of it, is required to admit that a person residing in another MS who negotiates with him a particular insurance product, which he would otherwise not have had access to it, benefit from the application of the law of his own country of residence to the detriment of the insurer's interest in using the law from his country. Moreover, for the insured as well who also has no other choice, because, despite the potential subject interest in being ruled by the insurers' law, he will not be able to do so by the demand of the Regulation - therefore,

\footnotetext{
${ }^{35}$ In cases like this, the risk is usually located in the country of residence of the policyholder. Therefore both through line a) and b) of paragraph 3 of article 7, the law that applies will be one of the country's residences of the policyholder. It is only in continuing cases that the policyholder will incur in another MS to insure a risk already in that other MS, in which through line a), it would be possible to apply a law other than that of his habitual residence.

${ }^{36}$ In the same way, as in C. BISPING, "Mandatorily Protected", 514: «Businesses typically contract on the basis of their standard terms and conditions. If the consumer's law would inevitably apply, then businesses could never rely on the prevalence of their terms and conditions».

${ }^{37}$ This idyllic idea of protection of policyholders that exists around paragraph 3 of article 7 only works in theoretical terms, since in practice, there may be certain differences that call our attention to this idea of protection. Sometimes the application of foreign law may be more favorable to the policyholder, even in the case of passive policyholders, and therefore in these situations, the letter of the law ends up going against the real interest of policyholders by not allowing the application of law from another MS. In favor of our reading (Idem).
} 
ULP Law Review | Revista de Direito da ULP

Vol. 13, n. .9

doi: 10.46294/ulplr13n1d5

that contract will be governed by the law of his habitual residence ${ }^{38}$. Only when the MS in which the risk is situated devote greater freedom of choice of law, can another result be seen.

Thus, an in-depth analysis of this article 7 thoroughly weakens the undertaking of insurances cross-border. According to the logic of the internal market, it does not seem reasonable at all that in a small way possible, a person could achieve an insurance contract subject to the law of another MS other than that of his usual residence. For this reason, it is essential to examine all the present solutions and state possible corrective sentencing measures to erase all these discrepancies, rising as a possible starting point, as to the evolution of the determining criteria of applicable law in order to guarantee the full satisfaction of the real interests of all parties, of the policyholders as well as of the insurers ${ }^{39}$ , be that as may, in the same criteria as of article $6^{40}$.

This issue becomes even more puzzling if we take into account the new distribution channels, which means a change in the way of negotiating insurances, especially with digital platforms.

\section{Conclusion}

The Rome I Regulation promised to bring enormous advantages, namely in the protection of policyholders and in the uniform treatment of the law applicable to the insurance contracts. However, the achievement of these objectives is questionable since the special conflict rule

\footnotetext{
${ }^{38}$ In the presence of a new mindset, «The main, traditional goal of consumer law was the protection of the weaker party for social reasons, the aim at present is increasingly dominated by the desire to strengthen the internal market. Accordingly, consumer confidence in the internal market should be increased in order to encourage those consumers to take advantage of the internal market to buy consumer goods in other Member States» (T. THIEDE and J. SCHACHERREITER, "The Recent Shift", 29).

${ }^{39}$ Insurers will benefit directly from the provision of greater freedom of choice of law on the part of policyholders, especially in cases of an active search for insurance contracts in which contracting with policyholders from other MS will no longer be harmful to them. This will certainly lead to a potential increase in regulatory arbitrage as, due to the greater willingness of insurers to establish legal relationships with policyholders residing in other MS, policyholders themselves will feel more willing and secure to go looking for insurance products outside the borders of their States.

${ }^{40}$ It shows up in defense of our point of view Helmut HEISS, "Insurance Contracts", 271.
} 
ULP Law Review | Revista de Direito da ULP

Vol. 13, n. .1

doi: 10.46294/ulplr13n1d5

corresponding to insurance contracts, presents quite cloudy and questionable solutions given the aims that would be pursued.

If in high-risk contracts, the objectives are met reasonably well, with the adoption of a relatively adequate criterion. As for mass contracts, we cannot say the same. There are rigid solutions that leave a lot to be desired, especially in the case of active insureds. Other options can be easily discussed, such as the repeated attribution, in the MS to define solutions that should be the Regulation to stipulate and not the internal legal systems.

As a way of safeguarding all interests in the equation, we are in favor of the need for a serious European debate on art. 7 after ten years of the entry into force of the Rome I Regulation. A more straightforward and more functional solution is intended, which in addition to safeguarding all the interests under discussion, allows for real uniformity in determining the law applicable to the insurance contracts.

Ultimately, greater predictability and legal certainty would encourage cross-border contracting in the EU by making legal relationships between insureds and insurers more secure. In this way, European citizens would have more confidence in the internal market to seek solutions across borders of their MS of origin under their freedom of movement. Unequivocally, regulatory arbitrage in the insurance field would be strengthened, as well as the transformation and adaptation of the insurance industry to the new social and economic realities. 